\title{
PEMBERIAN PREBIOTIK SOYBEAN OLIGOSAKARIDA DARI EKSTRAK BUNGKIL DAN KULIT KEDELAI TERHADAP PERLEMAKAN DAN BOBOT DAGING PADA AYAM BROILER
}

\author{
M. E. Krismaputri ${ }^{1}$, N. Suthama ${ }^{2}$ and Y. B. Pramono ${ }^{2}$ \\ 1) Mahasiswa Fakultas Peternakan Dan Pertanian Universitas Diponegoro \\ Kampus drh. Soejono Koesoemowardojo Tembalang Semarang 50275 \\ E-mail: melindaerdya@gmail.com \\ ${ }^{2)}$ Fakultas Peternakan dan Pertanian, Universitas Diponegoro \\ Kampus drh. R. Soejono Kusumowardojo Tembalang, Semarang 50275 \\ Diterima: 16 Maret 2016 Disetujui: 11 Oktober 2016
}

\begin{abstract}
ABSTRAK
Penelitian bertujuan untuk mengkaji pengaruh pemberian prebiotik soybean oligosakarida (SOS) dari ekstrak bungkil kedelai (EBK) dan ekstrak kulit kedelai (EKK) terhadap massa lemak daging, persentase lemak abdominal, dan bobot daging pada ayam broiler. Materi penelitian adalah 160 ekor ayam broiler strain Lohman unsex yang dipelihara selama 6 minggu. Penelitian menggunakan rancangan acak lengkap (RAL) dengan 5 perlakuan dan 4 ulangan, setiap ulangan menggunakan 8 ekor ayam broiler. Ransum perlakuan yang diberikan, yaitu T0 (ransum basal/RB), T1(RB+0,15\% EBK), T2 $(\mathrm{RB}+0,3 \% \mathrm{EBK}), \mathrm{T} 3(\mathrm{RB}+0,15 \% \mathrm{EKK}), \mathrm{T} 4(\mathrm{RB}+0,3 \% \mathrm{EKK})$. Data hasil penelitian dianalisis ragam dan dilanjutkan dengan duncan multiple range test. Hasil penelitian menunjukkan bahwa pemberian prebiotik SOS dari EBK dan EKK pada semua level berpengaruh nyata $(\mathrm{P}<0,05)$ terhadap persentase lemak abdominal dan bobot daging ayam broiler, namun tidak berpengaruh nyata $(\mathrm{P}>0,05)$ terhadap massa lemak daging.
\end{abstract}

Kata kunci: Soybean oligosakarida, bungkil dan kulit kedelai, massa lemak, lemak abdominal, bobot daging

\section{INFLUENCE OF PREBIOTIC SOYBEAN OLIGOSACCHARIDES FROM SOYBEAN MEAL EXTRACT AND SOYBEAN HULL EXTRACT ON THE MASS OF MEAT FAT AND MEAT WEIGHT IN BROILER CHICKEN}

\begin{abstract}
The study aims to examine the influence of prebiotic soybean oligosaccharides (SOS) from soybean meal extract (SME) and soybean hull extract (SHE) on the mass of meat fat, abdominal fat percentage, and meat weight in broiler chicken. The research material was 160 broiler chickens Lohman strain unsex maintained for six weeks. The study used a completely randomized design with 5 treatments and 4 replications, each replication uses 8 broiler chickens. Feeding treatments were: T0 (basal diet/BD), T1 (BD+0.15\% SME), T2 $(R B+0.3 \%$ SME), T3 (RB+0.15\% SHE), T4 $(R B+0.3 \%$ SHE). The data were analyzed using ANOVA followed by Duncan multiple range test. The results showed that administration of prebiotic SOS from SME and SHE at all levels significantly $(P<0.05)$
\end{abstract}


against abdominal fat percentage and weight of broiler meat, but not significant $(P>0.05)$ on meat fat mass.

Keywords: Soybean oligosaccharides, soybean meal and hull, fat mass, abdominal fat, meat weight

\section{PENDAHULUAN}

Imbuhan pakan sudah umum digunakan dalam usaha peternakan unggas modern untuk memacu pertumbuhan atau meningkatkan produktivitas dan kesehatan ternak serta meningkatkan efisiensi produksi. Imbuhan pakan yang sangat umum digunakan adalah antibiotik pada tingkat subtherapeutik, meskipun dampaknya terhadap kesehatan manusia mulai dipertanyakan (Sinurat et al., 2003). Haryati et al. (2010) melaporkan bahwa pada tahun 1969 dampak akibat penggunaan antibiotik yang berkelanjutan dan tidak sesuai anjuran menyebabkan resistensi bakteri pada ternak dan manusia sebagai konsumen terutama jika terdapat kandungan residu dalam produk ternak yang dikonsumsi. Penelitian yang mengeksplorasi tentang bahan alami sebagai pengganti antibiotik sudah banyak dilakukan, satu diantaranya adalah prebiotik. Haryati dan Supriyati (2010) menyatakan bahwa penggunaan prebiotik pada unggas semakin populer karena mampu meningkatkan populasi mikroba yang berguna dalam saluran pencernaan.

Salah satu jenis prebiotik yang berpotensi sebagai pengganti antibiotik adalah oligosakarida. Oligosakarida tidak dapat dicerna oleh inang, namun dapat difermentasi oleh bakteri menguntungkan yang ada dalam saluran pencernaan seperti Bifidobacteria dan bakteri asam laktat (BAL) (Haryati et al., 2010). Oligosakarida secara alami terdapat pada hasil tanaman salah satunya kacang kedelai. Limbah pengolahan kedelai seperti bungkil dan kulit kedelai mengandung oligosakarida atau sering disebut sebagai soybean oligosakarida yang dapat dimanfaatkan sebagai prebiotik. Fermentasi oligosakarida oleh bakteri dalam usus menghasilkan short chain fatty acids (SCFA) yang dapat menurunkan $\mathrm{pH}$ usus sehingga persentase bakteri menguntungkan meningkat, sedangkan persentase bakteri yang merugikan menurun. Bakteri menguntungkan dalam usus dapat menghasilkan enzim-enzim yang bekerja dalam mencerna lemak (Sjofjan, 2003). Mekanisme ini diharapkan dapat menurunkan massa lemak daging dan persentase lemak abdominal serta meningkatkan bobot daging pada ayam broiler.

Penelitian ini bertujuan untuk mengkaji pengaruh pemberian prebiotik soybean oligosakarida yang bersumber dari ekstrak bungkil kedelai dan ekstrak kulit kedelai ke dalam ransum terhadap massa lemak daging, persentase lemak abdominal, dan bobot daging pada ayam broiler. Manfaat dari penelitian yaitu bahan informasi ilmiah tentang massa lemak daging, persentase lemak abdominal, dan bobot daging pada ayam broiler dengan pemberian prebiotik soybean oligosakarida dari ekstrak bungkil dan kulit kedelai.

\section{MATERI DAN METODE Materi dan Peralatan Penelitian}

Ternak yang digunakan dalam penelitian ini adalah 160 ekor ayam broiler unsex strain Lohman (MB 202) umur 8 hari dengan bobot badan $112,24 \pm 6,70$ g/ekor 
yang dipelihara selama 6 minggu. Ransum basal yang diberikan tertera pada Tabel 1 . Penelitian menggunakan kandang koloni sebanyak 20 unit, masing-masing berukuran 120 x 100 x $60 \mathrm{~cm}$ yang dilengkapi dengan tempat pakan dan air minum, masingmasing kandang diisi 8 ekor ayam broiler.

Perlengkapan kandang lain yang digunakan adalah tirai plastik, lampu brooder, termometer, dan timbangan digital. Perlengkapan yang digunakan untuk processing adalah pisau bedah, gunting bedah, plastik dan nampan. Bahan kimia yang digunakan yaitu desinfektan, vaksin NDB1, ND Lasota dan Gumboro.

Tabel 1. Komposisi dan Kandungan Nutrisi Ransum Basal

\begin{tabular}{|c|c|c|}
\hline Bahan Penyusun Ransum & Starter & Finisher \\
\hline Jagung Kuning & -- & 55,8 \\
\hline Bekatul & 12 & 12 \\
\hline Tepung Ikan & 9,5 & 7 \\
\hline Bungkil Kedelai & 23,5 & 22 \\
\hline $\mathrm{CaCO}_{3}$ & 0,4 & 0,7 \\
\hline Vitamin dan Mineral & 0,3 & 0,5 \\
\hline Total & 100 & 100 \\
\hline \\
\hline Protein Kasar ${ }^{1}$ & 21,02 & 19,28 \\
\hline Lemak Kasar $^{1}$ & 6,08 & 6,04 \\
\hline Serat Kasar ${ }^{1}$ & 4,41 & 4,25 \\
\hline Kalsium $^{1}$ & 0,93 & 0,88 \\
\hline Pospor $^{1}$ & 0,64 & 0,58 \\
\hline Metionin $^{2}$ & 0,43 & 0,38 \\
\hline $\operatorname{Lisin}^{2}$ & 1,39 & 1,26 \\
\hline $\operatorname{Arginin}^{2}$ & 1,25 & 1,09 \\
\hline $\mathrm{EM}(\mathrm{Kkal} / \mathrm{kg})^{3}$ & 2900,13 & 2937,23 \\
\hline
\end{tabular}

${ }^{1}$ Dianalisis di Laboratorium Ilmu Nutrisi dan Pakan, Fakultas Peternakan dan Pertanian, Universitas Diponegoro, Semarang (2014); ${ }^{2}$ NRC (1994); ${ }^{3}$ Hartadi et al. (2005)

Rancangan Percobaan, Perlakuan dan Analisis Statistik

Penelitian menggunakan rancangan acak lengkap (RAL) dengan 5 perlakuan dan 4 ulangan, 8 ekor ayam pada setiap ulangan. Perlakuan yang diterapkan sebagai berikut:

$\mathrm{T} 0$ = Ransum basal $(\mathrm{RB})$ tanpa prebiotik soybean oligosaccharide (SOS)

$\mathrm{T} 1=\mathrm{RB}+0,15 \%$ SOS asal ekstrak bungkil kedelai $(\mathrm{EBK})$

$\mathrm{T} 2=\mathrm{RB}+0,3 \%$ SOS asal EBK

$\mathrm{T} 3=\mathrm{RB}+0,15 \%$ SOS asal ekstrak kulit kedelai (EKK)

$\mathrm{T} 4=\mathrm{RB}+0,3 \% \mathrm{SOS}$ asal EKK
Parameter yang diamati dalam penelitian ini adalah massa lemak daging, persentase lemak abdominal, dan bobot daging pada ayam broiler. Data yang diperoleh dianalisis ragam (analisis of variance) dan apabila terdapat pengaruh nyata $(\mathrm{P}<0,05)$ maka dilanjutkan dengan duncan's multiple range test untuk mengetahui perbedaan antar perlakuan. 


\section{HASIL DAN PEMBAHASAN}

\section{Pengaruh terhadap massa lemak daging}

Tabel 2. Rata-rata Massa Lemak Daging, Persentase Lemak Abdominal, dan Bobot Daging

\begin{tabular}{cccc}
\hline \hline Perlakuan & Massa Lemak Daging $(\mathrm{g})$ & $\begin{array}{c}\text { Persentase Lemak } \\
\text { Abdominal }(\%)\end{array}$ & Bobot Daging \\
\hline T0 & $15,73 \pm 4,50^{\text {ns }}$ & $1,55 \pm 0,03^{\mathrm{a}}$ & $405,00 \pm 29,64^{\mathrm{bc}}$ \\
T1 & $15,40 \pm 2,29^{\text {ns }}$ & $1,31 \pm 0,06^{\mathrm{b}}$ & $446,50 \pm 40,54^{\mathrm{bb}}$ \\
T2 & $13,98 \pm 4,24^{\text {ns }}$ & $1,34 \pm 0,08^{\mathrm{b}}$ & $472,75 \pm 28,61^{\mathrm{a}}$ \\
T3 & $14,55 \pm 1,36^{\text {ns }}$ & $1,52 \pm 0,14^{\mathrm{a}}$ & $379,25 \pm 30,13^{\mathrm{c}}$ \\
T4 & $15,53 \pm 3,30^{\text {ns }}$ & $1,57 \pm 0,10^{\mathrm{a}}$ & $387,50 \pm 60,14^{\mathrm{bc}}$ \\
\hline a, b, c C
\end{tabular}
$(\mathrm{P}<0,05)$

Hasil analisis statistik pemberian prebiotik soybean oligosakarida (SOS) dari ekstrak bungkil kedelai (EBK) dan ekstrak kulit kedelai (EKK) pada level 0,15\% maupun $0,3 \%$ tidak berpengaruh nyata $(\mathrm{P}>0,05)$ terhadap massa lemak daging pada ayam broiler seperti terlihat pada Tabel 2. Namun, pemberian prebiotik SOS secara numerik sedikit menurunkan massa lemak daging terutama perlakuan 0,3\% SOS asal EBK (T2) dibandingkan dengan kontrol. Adanya sedikit perubahan kadar massa lemak daging dapat diasumsikan karena pengaruh bakteri asam laktat (BAL) endogenous dalam saluran pencernaan ayam. Berdasarkan penelitian Wijayanti (2016) pemberian 0,3\% SOS asal EBK (T2) dan $0,3 \%$ SOS asal EKK (T4) menghasilkan BAL secara berturut-turut 10,42 dan 11,02 (10 $\mathrm{cfu} / \mathrm{ml})$. Bakteri asam laklat diketahui menghasilkan statin alami yang mampu menghambat pembentukan lemak di dalam hati. Menurut Cavallini et al. (2009) BAL menghasilkan statin yaitu inhibitor 3-hidroksi-3-metil-glutaril-KoA reduktase (HMG-KoA reduktase) yang bekerja dalam biosintesis lemak, kolesterol, lipoprotein darah dan trigliserida darah. Statin alami tersebut juga diduga menurunkan aktivitas enzim acetyl-CoA carboxylase (ACC) yang bekerja dalam sintesis asam lemak di hati. Menurut Ulupi dan Sumantri (2015) enzim ACC di dalam hati bekerja dalam mengubah acetyl-CoA menjadi malonyl-CoA, yang kemudian disintesis menjadi palmitat (asam lemak rantai panjang). Apabila aktivitas enzim ACC menurun maka sintesis asam lemak di hati juga menurun.

Kemampuan BAL dalam memproduksi enzim bile salt hydrolase (BSH) juga dapat menurunkan massa lemak daging ayam broiler. Enzim BSH bekerja dalam proses dekonjugasi garam empedu, karena garam empedu terkonjugasi dapat diubah menjadi garam empedu terdekonjugasi. Garam empedu terkonjugasi memiliki efektivitas emulsi lemak yang tinggi sedangkan garam empedu terdekonjugasi memiliki efektivitas emulsi lemak yang rendah di dalam usus sehingga terbuang bersama ekskreta. Menurut Astuti dan Rahmawati (2010) proses dekonjugasi ini terjadi karena BAL memproduksi enzim BSH yang dapat menghidrolisis atau memutuskan ikatan C$24 \mathrm{~N}$-acyl amida yang terbentuk di antara asam empedu dan asam amino pada garam empedu terkonjugasi. Terbuangnya garam empedu bersama ekskreta berdampak pada berkurangnya jumlah deposisi lemak, 
sehingga massa lemak daging menjadi rendah.

\section{Pengaruh terhadap persentase lemak abdominal}

Pemberian prebiotik soybean oligosaccharide (SOS) asal ekstrak bungkil kedelai (EBK) pada level 0,15\% (T1) dan $0,3 \%$ (T2) nyata menurunkan persentase lemak abdominal dibandingkan dengan kontrol (T0) maupun prebiotik SOS asal ekstrak kulit kedelai (EKK) pada level $0,15 \%$ (T3) dan 0,3\% (T4), sedangkan diantara T0, T3 dan T4 tidak berpengaruh nyata (Tabel 2).

Lemak abdominal pada ayam broiler terletak di sekitar organ dada, sekeliling gizzard dan pada saluran pencernaan ayam khususnya bagian belakang. Pemberian prebiotik SOS asal EBK (T1 dan T2) mampu menurunkan persentase lemak abdominal ayam broiler dibandingkan dengan kontrol (T0), yaitu sebanyak 0,21 $0,24 \%$. Berbeda halnya dengan perlakuan T1 dan T2, pemberian prebiotik SOS asal EKK (T3 dan T4) belum mampu menurunkan persentase lemak abdominal ayam broiler dibandingkan dengan kontrol. Kondisi ini terjadi karena prebiotik SOS asal EBK mengandung komponen utama senyawa rafinosa $0,73 \mathrm{~g} / 100 \mathrm{~g}$ dan stakiosa $0,90 \mathrm{~g} / 100 \mathrm{~g}$, namun EKK hanya mengandung senyawa stakiosa saja sejumlah 0,46 $\mathrm{g} / 100 \mathrm{~g}$ (dianalisis di Laboratorium Balai Penelitian Ternak, 2014). Berdasarkan perbedaan kandungan senyawa antara EBK dan EKK tersebut maka dapat dikaitkan dengan jumlah prebiotik SOS asal EBK lebih tinggi dibandingkan dengan yang berasal dari EKK. Senyawa rafinosa dan stakiosa yang lebih tinggi pada perlakuan T1 dan T2 dapat dimanfaatkan secara lebih efektif oleh bakteri menguntungkan dalam saluran pencernaan untuk menghasilkan asam asetat dan propionat. Hal ini dapat mengakibatkan $\mathrm{pH}$ di dalam saluran pencernaan ayam menjadi asam. Bakteri patogen diketahui tidak tahan terhadap keadaan asam, sehingga pertumbuhannya terhambat atau mati. Keadaan ini berpengaruh positif bagi keberadaan bakteri menguntungkan seperti bakteri asam laktat (BAL) dalam saluran pencernaan ayam. Peran BAL dalam menurunkan kadar lemak abdominal disebabkan BAL memiliki kemampuan mengurangi aktivitas enzim acetyl-CoA carboxylase (ACC) yang menstimulasi laju sintesis asam lemak di hati. Santoso (1995) melaporkan hasil penelitiannya bahwa suplementasi Bacillus subtilis efektif menurunkan aktivitas enzim acetyl-CoA carboxylase. Fenomena ini didukung hasil penelitian Kalavathy et al. (2010) bahwa suplementasi Lactobacillus efektif dalam menurunkan deposisi lemak abdominal. Enzim ACC diketahui berperan sebagai katalis dalam biosintesis malonylCoA dari acetyl-CoA. Malonyl-CoA inilah yang merupakan kunci dari sintesis asam lemak karena menghasilkan unit-unit karbon yang digunakan untuk memperpanjang rantai karbon asam lemak. Enzim ACC mengubah acetyl-CoA menjadi malonyl-CoA. Rantai asam lemak yang terbentuk diperpanjang melalui penambahan secara bersambungan unit-unit dua karbon yang disediakan malonyl-CoA. Mekanisme selanjutnya yang terjadi adalah hidrolisis lemak sehingga penyimpanan lemak abdominal berkurang. Menurut Sarwono et al. (2012), akibat dari menurunnya aktivitas enzim acetyl-CoA carboxylase maka merangsang sel-sel adiposa untuk menghidrolisis lemak sehingga jaringan adiposa termasuk lemak abdominal penyimpanannya menjadi berkurang. 


\section{Pengaruh terhadap bobot daging}

Hasil analisis statistik pemberian prebiotik soybean oligosakarida (SOS) dari ekstrak bungkil kedelai (EBK) dan ekstrak kulit kedelai (EKK) pada level $0,15 \%$ maupun $0,3 \%$ berpengaruh nyata $(\mathrm{P}<0,05)$ terhadap bobot daging pada ayam broiler seperti terlihat pada Tabel 2. Berdasarkan uji Duncan dapat diketahui bahwa pemberian prebiotik SOS asal EBK pada level $0,3 \%$ (T2) memiliki bobot daging lebih tinggi dibandingkan dengan perlakuan yang lainnya, meskipun demikian pemberian prebiotik SOS asal EBK pada level $0,15 \%$ (T1) menunjukkan hasil yang sama dengan perlakuan T2. Pemberian prebiotik SOS asal EKK pada level 0,3\% (T4) menunjukkan hasil yang sama dengan kontrol (T0), sedangkan pemberian prebiotik SOS asal EKK pada level 0,15\% (T3) memiliki bobot daging yang paling rendah. Rata-rata bobot daging ayam broiler pada penelitian ini berkisar antara $379,25-472,25 \mathrm{~g}$.

Efisiensi prebiotik SOS asal EBK oleh bakteri asam laktat (BAL) lebih baik karena kandungan senyawa dalam prebiotik SOS asal EBK lebih lengkap dibandingkan yang berasal dari EKK. Prebiotik SOS asal EBK mengandung komponen utama senyawa rafinosa $0,73 \mathrm{~g} / 100 \mathrm{~g}$ dan stakiosa $0,90 \mathrm{~g} / 100 \mathrm{~g}$, namun EKK hanya mengandung senyawa stakiosa saja sejumlah 0,46 $\mathrm{g} / 100 \mathrm{~g}$ (dianalisis di Laboratorium Balai Penelitian Ternak, 2014). Short chain fatty acid (SCFA) yang dihasilkan akibat dari fermentasi prebiotik SOS oleh BAL di dalam saluran pencernaan ayam mampu memperbaiki morfologi usus sehingga kesehatan inang terjaga. Menurut Langhout (2000) asam organik seperti asetat, propionat dan butirat dapat menurunkan produksi toksin oleh bakteri dan memperbaiki morfologi dinding usus, selain itu juga mampu mengurangi kolonisasi bakteri patogen. Apabila keseimbangan mikroflora usus terjaga maka terjadi peningkatan kesehatan inang yang pada akhirnya dapat memperbaiki performa ayam, pada penelitian ini ditandai dengan peningkatan bobot daging. Selain itu, meningkatnya bakteri menguntungkan dalam saluran pencernaan ayam dapat menstimulasi produksi enzim pencernaan menjadi lebih banyak sehingga penyerapan dan pencernaan nutrien ransum menjadi lebih baik. Menurut Wahyono (2002) bakteri yang berperan sebagai probiotik dapat menstimulasi sintetis enzim pencernaan sehingga meningkatkan penggunaan nutrien ransum. Kondisi ini secara langsung dapat dimanfaatkan oleh ayam untuk pertumbuhan dan perkembangan jaringan baru yang dapat mempengaruhi bobot daging.

\section{SIMPULAN DAN SARAN Simpulan}

Berdasarkan hasil penelitian dapat disimpulkan bahwa pemberian prebiotik soybean oligosaccharide (SOS) yang berasal dari ekstrak bungkil kedelai (EBK) terutama pada level lebih tinggi $(0,3 \%)$ mampu menurunkan massa lemak daging dan persentase lemak abdominal serta meningkatkan bobot daging pada ayam broiler.

\section{Saran}

Perlu dikaji lebih lanjut berkaitan dengan peningkatan level pemberian prebiotik soybean oligosaccharide (SOS) yang berasal dari ekstrak bungkil kedelai (EBK) dan ekstrak kulit kedelai (EKK), berhubung semakin tinggi level pemberian masih menunjukkan peningkatan performas. 
DAFTAR PUSTAKA

Astuti dan A. Rahmawati. 2010. Asimilasi Kolesterol dan Dekonjugasi Garam Empedu Oleh Bakteri Asam Laktat (BAL) dari Limbah Kotoran Ayam secara in vitro. Prosiding Seminar MIPA UNY, Yogyakarta.

Cavallini, D. C. U., R. Bedani, L. Q. Bomdespacho, R. C. Vendramini and E. A. Rossi. 2009. Effects of probiotic bacteria, isoflavones and simvastatin on lipid profile and atherosclerosis in cholesterol-fed rabbits: a randomized double-blind study. Bio. Med. Central 8: 1-8.

Haryati, T. dan Supriyati. 2010. Pemanfaatan senyawa oligosakarida dari bungkil kedelai dan ubi jalar pada pakan ayam pedaging. JITV 15 (4): 253-260.

Haryati, T., K. Suprijati dan I. W. R. Susana. 2010. Senyawa oligosakarida dari bungkil kedelai dan ubi jalar sebagai prebiotik untuk ternak. Seminar Nasional Teknologi Peternakan dan Veteriner. Hal.: 511-518.

Kalavathy, R., N. Abdullah, S. Jalaludin and Y. W. Ho. 2010. Effects of Lactobacillus cultures on growth performance, abdominal fat deposition, serum lipids and weight of organs of broiler chickens. British Poult. Sci. 44 (1): 139-144.

Langhout, P. 2000. New additives for broiler chicken: feed mix. The International Journal on Feed, Nutrition and Technology 9 (6): 2427.
Santoso. 1995. Effect of dried composition and Bacillus subtilis culture on growth, body hepatic lipogenic enzyme activity in female broiler chicks. British Journal of Nutrition 14: 523-529.

Sarwono, S. R., T. Yudiarti dan E. Suprijatna. 2012. Pengaruh pemberian probiotik terhadap trigliserida darah, lemak abdominal, bobot dan panjang saluran pencernaan ayam kampung. Animal Agriculture Journal 1 (2): 157-167.

Sinurat, A. P., T. Purwadaria, M. H. Togatorop dan T. Pasaribu. 2003. Pemanfaatan bioaktif tanaman sebagai "feed additive" pada ternak unggas: pengaruh pemberian gel lidah buaya atau ekstraknya dalam ransum terhadap penampilan ayam pedaging. JITV 8 (3): 139-145.

Sjofjan, O. 2003. Kajian Probiotik (Aspergillus niger dan Bacillus sp) Sebagai Imbuhan Pakan dan Implikasi Efeknya Terhadap Mikroflora Usus Serta Penampilan Produksi Ayam Petelur. Fakultas Pascasarjana, Universitas Padjadjaran, Bandung. (Disertasi).

Ulupi, N. dan C. Sumantri. 2015. Peranan kelompok gen triglyceride lipase, fatty acid synthase dan fatty acid binding protein pada metabolisme lemak ayam broiler. Wartazoa 25 (1): 15-22.

Wahyono, F. 2002. The influence of probiotic on feed consumption, body weight and blood cholesterol level in broiler fed on high saturated or unsaturated fat ration. J. Trop. Anim. Dev. 27: 36-44. 